\title{
A Semiotic Analysis of The Video Music: "Indonesia Bangkit": Comparing Audience Interpretation
}

\author{
Muhamad Gibraltar S. Sos., M. Si \\ Department of Communication, School of Law, Communication, and International Relations, President University, Bekasi, Indonesia
}

Email Address:

gibraltarmuhammad@gmail.com

\section{To cite this article:}

Muhamad Gibraltar. A Semiotic Analysis of the Video Music: "Indonesia Bangkit": Comparing Audience Interpretation. Humanities and Social Sciences. Vol. 2, No. 6, 2014, pp. 148-156. doi: 10.11648/j.hss.20140206.13

\begin{abstract}
When the political video clip "Indonesia Bangkit" appeared in the society, it created pros and cons particularly because one of personnel wore a dress like a Nazi uniform. In fact, this polemic makes it very valuable to become the unit of analysis. Furthermore, research objectives of this research proposal are to explore the myth buried in the music video, then, to examine the interpretation of the viewers when watching, and hearing a video music that includes when they see one of the personnel wearing Nazi uniforms. To answer first research question, Roland Barthes semiotic' thinking will be applied as Theoretical Container" filled with thoughts such as thinking Arthur Asa Berger, Darmaprawira, Mas Dian, Barker, and Mark L. Knapp (First Stage Analysis related to the research objectives first), followed by Susanne Langer's thoughts on "Discursive Symbolism" (second Phase Analysis of research related to the second goal). For the research method, it will be the literature study for the analysis of the first stage, followed by in-depth interviews at the second phase of the analysis. To sum up, it is only the research proposal, and it will not explore findings.
\end{abstract}

Keywords: Myth, Interpretation, Theoretical Container, Qualitative, Semiotic, Discursive Symbolism, Literature-Study, In-Depth Interview

\section{Background Information}

Political phenomenon such as general election sometimes make a tremendous effect in every aspect in our life. In many places, as a social fact, political occasion make an outstanding influence inside the society, including at the aspect of cultural industries, whose products such as: song, video music, video game, ads, and film. Since, these products just like tools of Propaganda, in order to win political candidates at the political contestation. And, it is happened around the world.

Since emotion and cognition are very important in political campaign, since the 1990s, a substantial body of political communication studies has provided evidence of the influence of news, political campaigns, and political advertising on citizens decision-making processes. Most of these studies identified message content and policy issues as the primary factors in political decision-making. However, an increasing number of studies emphasize the role of emotional appeals contained in political campaigns. (Castells, 2009: 150-151)

Usually, in United States, vote can be explained by two variables: feeling toward the party, and feeling toward the candidate, while policy issues weighed much less in voters decisions. Moreover, policy issues become important primarily when they arouse emotions among the voters. (Castells, 2009: 150)

Since people's mind are constructed through their experience, political advertising and political campaign aim to connect specific image with specific experiences to activate and deactivate the metaphors that are likely to motivate support for a given political actor. (Castells, 2009: 153)

This situation was also happened in Indonesia. The existence of political video music: Indonesia Bangkit made the polemic inside the society. In fact, it supports one of presidential candidates of Indonesia: Prabowo Hatta.

Unluckily, it must be known that YouTube has erased it from its website because Brian May (the author of this song) has remarked (supported by EMI claim) that Ahmad Dhani as the musician does not have a permission to use and change that song for any purposes. (Agustinus Sindu Alpito, YouTube Tarik Video: Indonesia Bangkit Ahmad Dhani,http://showbiz.metrotvnews.com/read/2014/06/28/258 
354/youtube-tarik-video-indonesia-bangkit-ahmad-dhani.

Accessed at October 1st, 2014)

Moreover, the con also came from the Prabowo Hatta side. Mr. Hidayat Nur Wahid, the spokesman, said that it would harm the electoral position of the candidate. In addition, Hidayat Nur Wahid also showed the disagreement about the NAZI uniform and atribut. Also, Times and Der Spiegel Magazine reacted negatively about it, (Tim Prabowo Hatta Minta Ahmad Dhani Klarifikasi Video Klip Beratribut Nazi. http://www.voaindonesia.com/content/tim-prabowo-hattaminta-ahmad-dhani-klarifikasi-video-klip-beratribut-nazi-

/1945267.html. Accessed at October 1st, 2014)

On the contrary, Fadli Zon (The Vice Chief of Gerindra Party) said that it was the best video clip for this year General Election. Fadli Zon also commented that it was very good which made Prabowo Hatta political opponent sweated. (Fadli Zon "Indonesia Bangkit" Ahmad Dhani Video Klip Terbaik di Pemilu Kali ini. http://www.jpnn.com/read/2014/06/27/242786/Fadli-Zon:Indonesia-Bangkit-Ahmad-Dhani-Videoklip-Terbaik-diPemilu-Kali-Ini- . Accessed at October 1st, 2014)

Many Solo (one of cities in Middle Java Province, Indonesia) citizens dissapointed about the music clip. One of them is Sri Hartanto who analogize it directly with cruelty of NAZI historically. , (Tim Prabowo Hatta Minta Ahmad Dhani Klarifikasi Video Klip Beratribut Nazi. http://www.voaindonesia.com/content/tim-prabowo-hattaminta-ahmad-dhani-klarifikasi-video-klip-beratribut-nazi/1945267.html. Accessed at October 1st, 2014)

But, it is just only one testimony. It means that it needs more exploration to know deeper about the interpretation of viewers about the hidden myth. In this case, the writer tries to be very neutral.

To Summarise, the polemic makes something worth to become something. In this case, it is very precious to be examined by research.

\section{The Objectives and Theoretical Frameworks}

In the previous description, it is mentioned that the Video music "Indonesia Bangkit" has caused controversy in the community. So it is important to use Roland Barthes' semiotic thinking, altogether with the Susanne Langer Discursive Symbolism to explore it deeply.

However, it has not finished yet, in which there is a sort of dynamics. Certainly, what is referred to as signified and signifier in this matter is those found in the denotation system level in Roland Barthes' semiotics. The object to be studied is actually found in the connotation system level (connotative meaning of signified and signifier). In the first research question, the main logical framework used is Roland Barthes' semiotics. (Gibraltar, 2014: 124)

However, in the second question, an additional logical framework is used, namely: Susanne Langer's thought which may connect the difference between sign and symbol. The main issue is Signifier and Signified, on both the denotation and connotation levels, considering that these two cause different interpretation among viewers, particularly when sign changes into symbol.

Therefore, the issue in the present research is as follows:

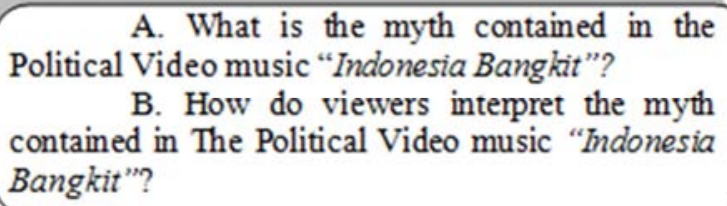

Then, the objective to be achieved in this research is as follow:

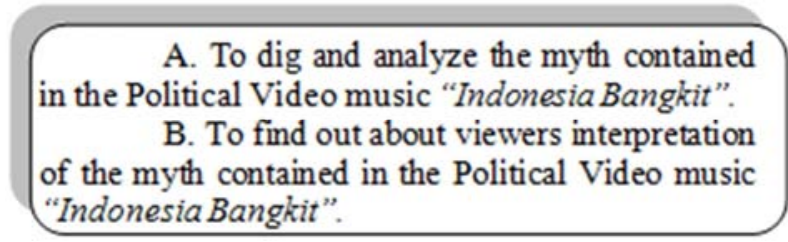

In order to answer the first research question, Roland Barthes' semiotic logical framework will be used. The description is as follows:

Roland Barthes' thought is described in the form of scheme. In brief, this is the "theoretical container" which will become the stepping stone of the analysis in the present research, while other theories (such as the theoretical development of Charon's symbolic interactionism, which later became more specific in Arthur Asa Berger's discussion on the concretization of signifier and signified, Barker's thought about the relationship between colors and moods, and Knapp) about nonverbal will become the "analytical knife" which fills the boxes in the scheme created by Roland Barthes, particularly box number 4: "Connotative Signified"; the box in which the interpretation of denotation system is conducted by the semiotic researcher.

Therefore, the starting point in this research is the "Second Level Signification", more specifically the "Connotative Signified".

The connecting line is that the whole sign-related logical framework is placed in the fourth column (connotative signified). As the result, what we can describe here is not only the social constructions hidden in "Indonesia Bangkit" but also various interpretations of signs in the form of colors, appearance, and nonverbal.

There are a number of logical frameworks used to fill in the column number 4 (connotative signified). Subsequently, we will make it concrete with Mark L. Knapp's thought about the nonverbal concept, to the meaning of a color by Barker. The following is their respective narratives based on the matter.

Mark L. Knapp explained that the term nonverbal is usually used to describe all communication events other than said and written words. In this definition, nonverbal events and behavior are not really nonverbal in nature. The nonverbal field is an area which emphasizes the importance 
of phenomenon which is empirical, factual and concrete in nature, without speech and language. It means that the nonverbal field is related to concrete, real matters which can be proven through human senses. (Wibowo, 2011: 72)

The concretization of this thought is as expressed by Arthur Asa Berger in the following: (Sobur, 2009: 174-175)

Table 1.1. The Concreteness of Signifier and Signified

\begin{tabular}{ll}
\hline Signifier & Signified \\
\hline 1. Long hair. & Not according to the culture \\
2. Neat hair. & Entrecially if the hair looks shabby). \\
3. Hair that cut too short. & Gays and soldiers / both. \\
4. Brown brick. & Hate sports, leisure activities. \\
5. Pale. & Intellectuals (or person who were \\
6. Levi's & sick). \\
7. Jean particular design results. & Casual clothes, the proletariat. \\
8. Jean K. Mart. & Respected, or luxury. \\
9. Three sets of formal clothes. & Workers. \\
10. Suitcase. & Executives, entrepreneurs. \\
11. Diplomatic bag. & Old fashioned, traditional. \\
12. Handbag. & Type a successful entrepreneur. \\
13. Backpack. & European style, Italian descent. \\
14. Shopping Bags. & Nomad. \\
15. Sandals. & Farmers. \\
16. Winged. & Artists. \\
17. But for workers. & Type of entrepreneur. \\
18. But nomads. & Workers. \\
19. Pilot glasses. & Nature lover, wanderer. \\
20. Glasses with the chain. & Middle class. \\
21. Dark glasses / black. & Freak. \\
22. Tie with the knot ties. & Type the streets, people who are \\
23. Thick tie. & crazy. \\
24. Tie like a rope. & Educated people. \\
\hline & Ancient people. \\
\hline & Villagers, Western Nations. \\
\hline
\end{tabular}

The last one is related with colors. Everybody certainly has a favorite color. And usually, this color affects their mood. The following is a description of mood associated with colors as stated by Barker. (Sobur, 2009: 174-175)

Table 1.2. Color Associated Mood

\begin{tabular}{ll}
\hline Mood & Color \\
\hline Exciting, Stimulating & Red \\
Safe, Comfortable & Blue \\
Depressed, Disturbed, Confused & Orange \\
Gentle, Soothing & Blue \\
Protect, Defend & Red, Brown, Black \\
Very Sad, Heartbroken, Unhappy & Black, Brown \\
Calm, Peaceful, Serene & Blue, Green \\
Dignified, Regal & Purple \\
Fun, Carefree, Happy & Yellow \\
Challenging, against hostile & Red, Orange \\
Powerful, strong, very good. & Black \\
\hline
\end{tabular}

Moreover, the element of color is an essential element in the visualization advertising. Colors have an important role in creating the meaning of these ads, especially in terms of emotions and feelings. On art, symbolic use of color is considered an important event. According Darmaprawira, picture colors have some symbolic value in general, include:

\section{(Darmaprawira, 2002: 45-49)}

Red: Of all the colors, red is the color of the strongest and most interesting, aggressive symbol of the primitive. This color is associated as blood, angry, brave, sex, danger, strength, virility, love, and happiness.

Purplish red: red-purple color has anything noble, grand, rich, proud (arrogant), and impressive.

Purple: This color is characteristic cool, negative, backward, similar to but blue sink and solemn, moody character and has given up. This color symbolizes mourning. Contemplative, sacred, religious symbol.

Blue: Character cool, passive, quiet, and peaceful. Goethe mentions as dazzling color, spiritual, monotheistic, lonely, this time thinking about the past and future. Blue is a color perspective, draws us to solitude, cool, separate and create distance. Blue symbolizes the sanctity of hope and peace.

Green: Symbolizes contemplation, faith (religion) and immortality. Also, it reveals freshness, raw, young, immature, growth and hope, rebirth and fertility. The negative side of the green is not a favorite of children, the color associated disease, hatred, venom and jealousy.

Yellow: Symbolizes enjoyment, agility, and intellectual well explain the glory of love as well as a deep understanding of the relationships between people.

White: Having a positive character, stimulating, bright, light and simple, it also symbolizes purity, innocent, honest, and pure.

Gray: It symbolizes calmness, polite and modest. Also, symbolizes intelligence, but has a negative symbol of the doubt. Symbolizes nature neutral mediator in the conflict.

Black: Symbolizes darkness and absence of light. Signifies the dark forces, the symbol of mystery and color of the night.

Often also denoted as color destruction or mistake. Black can also indicate a firm stance, firm, formal, robust structure.

Moreover, a Feng Shui consultant, Mas Dian, in his book The Effect of Color in Feng Shui," published in 2002, suggested that the color has a characteristic trait expressly affect a person's psychic and can provide a variety of inspirations that evoke emotion. He also outlined that the language of color has a different meaning, such as, among others, (Dian, 2002: 1-2):

Pink: Describing feminine, soft, soft, beautiful, and romantic.

Red color: Deciphering energetic, powerful, dynamic, active, and heat.

Cream color: Symbolizes gentle, classic, exclusive, neutral, warm, and sweet.

Orange color: describes carefree, popular, loud, bright, hot, and passionate.

Color Pale Yellow: represents nature chirpy, sunny, warm, soft, pretty, and sweet.

Color Light Green: describe fresh, happy, cheerful, and growth.

Color Green: describes classical, cool, worldly, exclusive, and quiet.

Color Light Blue: symbolizes calm, clean, cool, peaceful, gentle, and relaxed. 
Blue color: describes classical, strong, confident, calm, and professional.

White color: describe the nature quiet, pure, clean, chaste, classical, sheen, and grief.

Color Black: symbolizes the nature of classical, elegant, mystical, powerful, tough, sexy, and dramatic.

Color Silver: describe an exclusive or expensive, elegant, classic, and cool.

Gold Color: symbolizes the impression energetic, powerful, dynamic, active, and heat.

Back to Arthur Asa Berger. He also formulates other theories that are important for this research, including:

Table 1.3. Size Image Capturing (Adityawan, 2008: 41)

\begin{tabular}{|c|c|c|}
\hline $\begin{array}{l}\text { Signified of } \\
\text { Taking Picture }\end{array}$ & Definition & Signifiers \\
\hline Close Up & Only the face & Intimacy \\
\hline Medium Shot & Nearly the Entire Body & Personal relationships \\
\hline Long Shot & Setting and characters & Context, scope, distance \\
\hline Full Shot & The whole body & $\begin{array}{l}\text { Public personal } \\
\text { relationships }\end{array}$ \\
\hline
\end{tabular}

Table 1.4. Motion Picture Cameras and Substitution of Picture (Adityawan, 2008: 41)

\begin{tabular}{|c|c|c|}
\hline Signified & Definitions & Signifiers \\
\hline $\begin{array}{l}\text { Pan } \\
\text { Down }\end{array}$ & Camera pointing down & Power, authority \\
\hline Pan Up & Camera pointing upwards & Weakness, diminution \\
\hline Dolly In & The camera moves to the & Observation, focus \\
\hline Fade In & Images look at a blank screen & beginning \\
\hline Fade Out & Image on the screen to be lost & closure \\
\hline Cut & $\begin{array}{l}\text { Move from one image to } \\
\text { another }\end{array}$ & Continuation, interesting \\
\hline Wipe & Erased from the screen image & "Determination" conclusion \\
\hline
\end{tabular}

Table 1.5. Visual Languages and Its Significance (Adityawan, 2008: 42) (See on the next)

\begin{tabular}{lll}
\hline Sign & Importance & Unimportance \\
\hline Size / Scale & Large More Great & Small \\
& From & More Small / Equal \\
& Around & Around \\
Position & Middle & Edge \\
& Front & Back \\
& Above & Under \\
Angle / Location of Camera & Left-Upper & Right-Down \\
Light Figure / & Under Objects & Above Object \\
Object & Light & Dark \\
Background light & Light & Dark \\
Focus / Depth of Field & Clear / Sharp & Blurred / Samar \\
frequency of Appearance & Often Shown & Rarely Shown \\
accent & It Differs From & \\
\hline
\end{tabular}

In addition, the thought of Joel M. Charon about symbolsis still too "Grandiose" and therefore need to be specified as the analytical tool in this research. (Gibraltar, 2014: 126)

As the result, it can be ensured that the thought of Darmaprawira and Mas Dian are extremely necessary as the analytical tool in this research.
The connecting line is that the important aspects to be studied in the research on video music are the aspects of color, dialogue and nonverbal.

Then, we continue with the second logical framework to answer the second research question. We move to the thought on "Discursive Symbolism" proposed by Susanne Langer. One of the important language theories is her "philosophy of the new key", which received various deep attention from many scholars who adhere to symbolism. According to Langer, the whole life of an animal is dominated by feelings, but human feelings are affected by conceptions, symbols, and languages. Susanne Langer said that "Symbols are not proxy of their objects but are vehicles for the conception of objects". In other words, a symbol is "an instrument of thought”. (Littlejohn and Foss, 2002: 61-62)

Not only having the capacity in using symbols, but the community also has a need for those symbols, and the creation of symbols is an ongoing process, similar to the activities of eating and sleeping. Most of human behavior can be explained by the term of need for symbols. (Littlejohn and Foss, 2002: 62)

Then, how does a symbol work? Various types of symbols, including preposition, communicate a concept, general ideas, pattern or certain shapes. Concept is something whose meaning is shared between the communicators; however, each communicator also has a private image of the meaning of the symbol, which fills the details of a general image. This private image is referred toas a person's conception. (Littlejohn and Foss, 2002: 62)

A brief description of concept. Susanne Langer used the word "oscillation" as an example. A person may privately see it as the Swing of Pendulum, the shake of a skyscraper, the vibration or trill on a violin's string in accordance with the direction of the bow, the clenching of our teeth in a cold weather, etc. From all of these examples, we can draw a "logical form" as "a concept of oscillation", or "rhythmic motion to and fro". (Langer, 1967: 35-36)

In another literature, it is explained that a meaning, therefore, consists of an individual conception which is private in nature, and a general concept shared with other persons. For example (Stephen L. Littlejohn and Karen Foss used this as an example), Vincent van Gogh's paintings which contain general symbols and private meanings. The private meanings of these paintings can be obtained by any person; they generally recognize these paintings. Such private meaning belongs to van Gogh himself and any person who has studied art. (Littlejohn \& Foss, 2002: 62)

The most important thing in Langer's thought is the three additional terms, namely signification, connotation, and denotation. Signification is the meaning of a sign, or a simple stimulus informing about the presence of one/more objects. Signification is a one-to-one relationship between asign and an object or between the stop sign and the walk sign for pedestrians. (Littlejohn \& Foss, 2002: 63)

The logical framework placed in subchapter 2.1 In Order to Answer the First Research Question: Discussing about Sign will be used in this phase (signification), such as Roland 
Barthes' semiotic thought, Arthur Asa Berger (concretization of signifier and signified), Barker (colors and moods), Mark L. Knapp (nonverbal), Darmaprawira and Mas Dian (analysis of colors), particularly in digging the signifier, signified and social constructions hidden in the Political Video music: Indonesia Bangkit.

In Susanne Langer's vocabulary, denotation is the relationship between a symbol and its object. For example, the denotation of the symbol "dog" in a person's mind is a brown-furred puppy sitting on the person's feet, even if the puppy does not really exist. On the contrary, connotation is a symbol which represents direct relationship between a symbol and conception. Connotation includes a person's personal feelings and associations attached to the symbol. For example, a puppy which stirs up a person's happy childhood memory, and so on. (Littlejohn \& Foss, 2002: 63)

The result of the communication process is referred to as interpretation. Interpretation is a process of forming a general idea based on various concrete experiences. The process leaves certain details in revealing objects, phenomena or situations in more general context/terms. Any continuing terms in this process will leave more details compared to the previously existing terms. In brief, Susanne Langer's thought can also be referred to by the term no presentational symbol. (Littlejohn \& Foss, 2002: 63)

Interpretation itself is conceptualized as an awareness of form, which contains matters of general analogous nature, (most importantly) separated from its content, and more correctly referred to as "concrete integuments". In addition, any interpretation must have the same patterns with one or two interpretations, like the inches in a ruler, steps on a ladder, continuation of Encyclopedia Britannica volumes, or interval between one US President and another US President. Interpretation (among others) consists of denotation and connotation. (Langer, 1967: 33)

Susanne Langer also explained that there is nothing difficult in understanding an abstract thought (making interpretation). This is not something abstract which can only be understood by a small number of people. As Lord Russell said: every person has "the forms of logics of some knowledge; and what must be done (by the person) is to make it more explicit, realized and familiar/easy to recognize". This is the form which will attract us, and not a medium in which the form is expressed. (Langer, 1967: 35)

In brief, interpretation referred to by Langer is the "interpretation of an abstract form". This is a process to see everything where everything comes from. For example, if we are interpreting the abstract concept of "rotation", we will think about the spin of a wheel, the movement of a body, the spin of a propeller, and so on. (Langer, 1967: 37)

This is how Susanne Langer's thought is explained, starting from the difference between sign and symbol, conception, to the difference between signification, denotation, and connotation; in which all of these will create certain interpretation if (the signal) reaches the viewers. This is what differentiates Susanne Langer's thought on "discursive symbolism" from other symbolic thoughts which are non-representational in nature. (Gibraltar, 2014: 127)

The conclusion is that there is an "interaction" between signified, signifier and viewers' understanding, which will later affect viewers' interpretation of "Indonesia Bangkit" in which the signs create individual interpretation for theviewers who watch them.

This research uses the "triangulation of theory", which is practiced when the researcher uses various theoretical perspectives in performing the planning phase of a research, or when interpreting data. For example, the researcher plans to conduct research by using the concepts anassumptions of the conflict theory and at the same time the exchange theory (Neumann, 2006: 150). It is also the same with this research, in which the researcher uses the sign theory and the symbolic theory. (Gibraltar, 2014: 127)

Before closing the discussion of this chapter two, the following is the theoretical scheme which rationalizes the whole logical framework above, both the one discussing about sign as well as the one discussing about symbol after the signal of the sign has been caught, and creates interpretation of signifier and signified for the viewers who watch it. (Gibraltar, 2014: 128)

Before closing the discussion of this subchapter, the theoretical logical flow of this research (first phase) is as follows:

\section{A First Phase: Semiotic Analysis}

Roland Barthes' semiotic thought in digging hidden signifier and signified as the "theoretical container", which includes: the Semiotic Analysis of Arthur Asa Berger (concretization of signifier and signified), Barker (colors and moods), Darmaprawira and Mas Dian (colors), and Knapp (Nonverbal). (Gibraltar, 2014: 128)

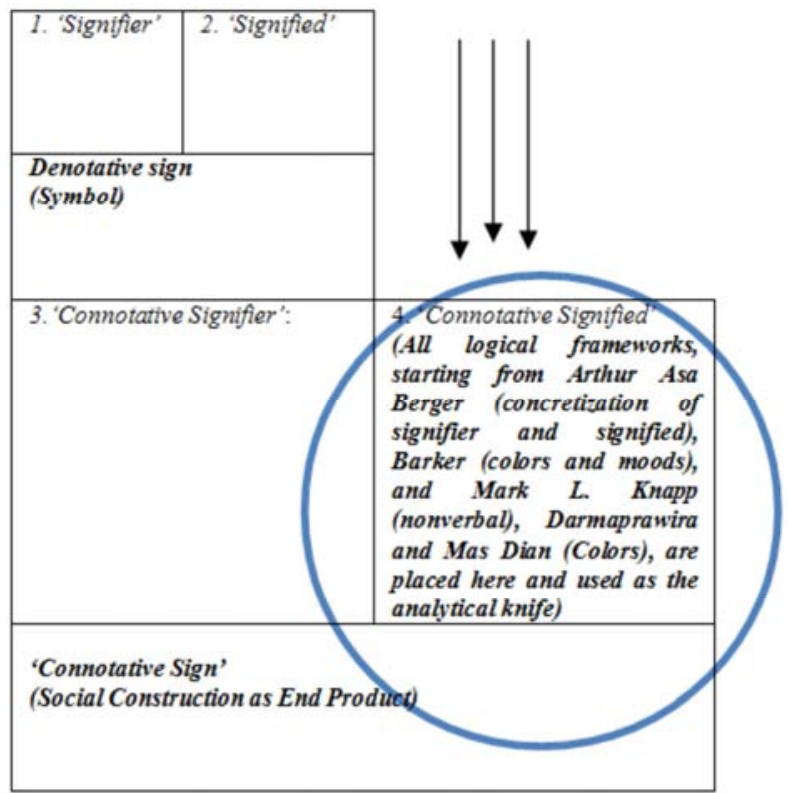

(Gibraltar, 2014: 28)

B B. Second Phase:

Using Susanne Langer's thought on Discursive Symbolism (Langer, 1967:38): Discussing about Symbol (because the signs contained in the Political Video music: Indonesia 
Bangkit have been seen by viewers, and therefore create an interpretation in the mind of each of the viewers.

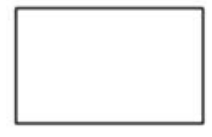

Television aired the

Music clip: Indonesia

Bangkit

(Gibraltar, 2014: 128)

\section{Methodology}

This study uses the interpretive paradigm by combining two types of research methods, namely literature study and In-Depth Interview, using semi structured questions. In addition, the data analysis method uses is the illustrative method, which sees everything as an empty glass filled with water, and triangulated using the "negative sentance method" as a comparison in order to comprehensively obtain a qualitative explanation. (Gibraltar, 2014: 128)

The location taken place consist of 4 cities, specifically 2 industrial cities, and 2 cultural cities. For industrial cities, Bekasi and Tangerang are chosen because many factories and plants are located there, which means that many labors live in Bekasi and Tangerang.

In addition, for the education cities, Yogyakarta, and Depok will be selected because Yogya has Gadjah Mada University, and Depok has University of Indonesia, which means the development of life and industries always correlates with the educational institution, and many students live in Yogyakarta and Depok.

From my perspective, the interpretation between labors and students are different. Students are more science-oriented rather than labors. On the other hand, labors are more moneyoriented because of the pressure of life.

Also, life in both types of cities is different rapidly. In education cities, life rhythm is slower than industrial cities, and it can be seen from the traffic condition; people drive their vehicle at the lower speed rather than industrial cities. In contrast, life rhythm in industrial cities is faster and harder than education cities; indeed, labors commonly buy things (such as the expensive motorcycles, cars) first and pay installments, so that when their job-contracts are finished, they already have something in life.

Back to this research, two types of methods for selecting informants will be used, which is certainly classified as "Non Probability Sampling".

The first one is "Theoretical Sampling", which is conceptualized as nonrandom sample in which researcher selects specific times, locations, or events to conduct observation in order to develop a social theory or to evaluate theoretical ideas (Neumann, 2006: 224). This method is used because the researcher has identified precisely the time, location, event, and even who are the informants who will be questioned related to the Political Video music: Indonesia Bangkit.

The objective of theoretical sampling is to find the manifestations of the construction of interest in order to elaborate and examine the construction along with its variations. (Patton, 2002: 243)

However, in order to improve the quality of this research, The Snow Ball Sampling method for selecting informants will also be used, which is interpreted as nonrandom sample in which the researcher starts with one case, and based on information about the interrelationship of this case, other cases are identified, and the process will be repeated. (Neumann, 2006: 223)

The objective of "snowball sampling" is to identify the cases of interest from people who knows which cases are rich of information, which can be used as a study, and for interviewing the right participants. (Patton, 2002: 243)

Procedurally, snowball sampling, both using the probability as well as non-probability techniques, is conducted in several phases. In the first phase, a number of persons with the same characteristic are identified and interviewed. These people are used as informants to identify other persons who may be selected into the sample. In the second phase, the researcher interviews the persons recommended in the first phase, who will subsequently give the names of persons who can be interviewed in the next phase. (Nurhidayat, 2002: 376)

The objective of the use of this method is to complement the "Theoretical Sampling" method, in order that the previously stipulated informants can give recommendation about new informants who can be asked about information.

The number of informants targeted is 10 persons, in which each Cities contributes 2 persons (one male and one female) who are selected using the Snowball Sampling, and Theoretical Sampling. The Remaining two persons are selected using the theoretical sampling with the specification that they must be an expert in video music: one expert from the professional who commonly make a video music, and one musician who understand about the song, rhythm, melody, tone, etc. In this case, the musician must be Ahmad Dhani himself because his opinion must be regarded.

\section{How Will the Research be communicated to the Broader Community?}

This research can be communicated to the broader community, considering its wide scientific potential. Analyzed from this aspect, the result of this research can be communicated to the multidisciplinary scientific community other than communication sciences, starting from the literature, business, economics and cultural studies. (Gibraltar, 2014: 129)

In fact, Roland Barthes semiotic thought is positioned as an elevator which may go up and down (Gibraltar, 2014: 
129). It means that it answers not only the needs of communication science, but also the needs of other sciences, including arts.

Moreover, this research can also be extended to the scene domain, since video music cannot be separated from it. Scene is also closely related to semiotics, and can make the semiotic approach become more productive (Gibraltar, 2014: 129), to commensurate with the opinion made by Barry Shank: "Within a scene, far more semiotic information is produced than can be rationally parsed" (Straw, 2005: 412). Even if, the scene study rejects deciphering, this unifies the cultural energy which can create a collective identity (in this case the myth). (Straw, 2005: 412)

\section{The Supervisory Provision as Well as Specialist and Transferable Skills Training}

This research is very important especially for the development of science at two subjects at President University: The Sociology of Communication, and Theories of Communication. Myself as the lecturer of these subjects wants give a precise example how to use semiotic approach at the actual case.

In fact, I have written one conference proceeding about Indonesian video game (Gibraltar, 2014), one research article about Indonesian ads (Gibraltar, 2014), one research proposal about Indonesian Action Film (Gibraltar, 2014). Now it is time to adaptate the semiotic approach to examine Political Video music as the unit of analysis.

Indeed, the author prepared this research plan in order to create the new perspective in Communication Studies at School of Communication, Law, and International Relations, Department of Communication, President University. Moreover, most of streams of communication science in Indonesia relate to Journalism. I believe that this proposal can "wake up" students that arts approach, including semiotic approach is beneficial in communication science, not only in class, but also at the actual research.

Also, many students want to bring the semiotic approach into their thesis, and analyze the ads, video game, film, song (including video music). Hopefully, this research proposal will ease them to structure their thesis by using it as the academic reference and example.

\section{Ethical Considerations}

In order to strengthen the seriousness / relevance of this research, the researcher has prepared Goodness Criteria, for assessing and interpreting data. For that purpose, the researcher selected goodness criteria. They are:

A Completeness of Descriptions: or more precisely, how complete is the researcher's explanation of a social phenomenon, in accordance with the theoretical framework which has been developed.

B Authenticity: as a certification or benchmark of quality of the researcher's presence in that setting.

C Ecological Validity: Is the explanation of social phenomenon made by the researcher in accordance with the real condition on field?

D Credibility: the bridge between researcher's interpretation and reality.

E Plausibility: Seeing the consistency between the researcher's findings and the theories accepted and recognized by the scientific community.

(Seale et al, 2007: 377)

Then, what has been made by this study in implementing or achieving these "Goodness Criteria"? The following are several things conducted by the researcher:

A This research will explain to the details at the semiotic analysis level about interpretations of signs contained in the video music. Not only using the thought of Roland Barthes (considering that this is not sufficient), but also using other thoughts such as the thoughts of Barker, Mark L. Knapp, Arthur Asa Berger, Darmaprawira and Mas Dian. This is because a study about movie is a complex study, not only involving content, expression, and representation, but also movements), colors, facial expressions, sounds, etc. (Completeness of Descriptions)

B Researcher presents the complete verbatim quote of the five informants in the attachment to this research, as the proof of the researcher's presence at the research location. (Authenticity)

$\mathrm{C}$ The real condition happening in the community must be clearly described, that is why the researcher uses Susanne Langer's thought on "Discursive Symbolism", which attempts to establish a connection between sign and symbol. (Ecological Validity)

D It is also the case with "Credibility" in which Susanne Langer's thought will play the role of bridge between sign and symbol, and at the same time the connector between reality and the researcher's interpretation.

E Finally, the researcher will use Roland Barthes' logical framework and other logical framework in order that the already developed theoretical frameworks do not go anywhere, but are locked in the thought. (Plausibility) (Gibraltar, 2014: 129-130)

\section{Summary and Conclusions}

This is very unique research proposal. In fact, it starts from the polemic inside the society about the existence of the political video music: "Indonesia Bangkit". Since it is shown that one of singer at the video music wore the NAZI Uniform; indeed, this sign makes a contradiction inside the Indonesian society. Fortunately, this phenomena makes it becomes very interesting to be the unit of analysis, particularly to dig the myth inside the political video music, and identify the viewers interpretation when they watch it, including what's interpretation that will appear when they see the NAZI uniform, worn by one of personnels at the video music. 
It means, the first and second research questions would be (A.) What is the myth contained in the Political Video music "Indonesia Bangkit"? (B.) How do viewers interpret the myth contained in The Political Video music "Indonesia Bangkit'?

To answer the first, it will be used the Semiotic Thought of Roland Barthes in order as the "Theoretical Container", combined with the thoughts from Arthur Asa Berger (Concreteness of the Signifier and Signified), Darmaprawira, Mas Dian, (Local Color Theories), and Mark L. Knapp (Nonverbal). Moreover, to explore about the second, The Discursive Symbolism of Susanne Langer is believed to be the most appropriate theoretical framework for it.

For the methodology, the triangulation between the literature study (to answer the first question), and the InDepth Interview is very appropriate for this proposal, in order to obtain the qualified data from the exact source.

In fact, this research can be broadened into wider academic area beyond the communication science, such as: Economics, Business, Literature, and Arts; since the theoretical framework is very elastic like an elevator, can go up (theoretical level) and down (methodological level) depends on the needs of research.

Since video music is tasted by using scene, it can be broadened to that specific academic area.

The invention of this research proposal is based on the needs of two subjects: The Sociology of Communication, and Theories of Communication. Hopefully, it can ease student at their study, particularly when they make a thesis before graduation.

Lastly, this research plan can be accounted according to five characteristics: Completeness of Descriptions, Authenticity, Ecological Validity, Credibility, and Plausibilty.

All in all, the writer hope that it can support the development of Humanities and Social Sciences in the future.

\section{References}

[1] Adityawan, Arief. (2008). Propaganda Pemimpin Politik Orde Baru (Propaganda of the New Order's Political Leader). Jakarta: LP3ES.

[2] Alpito, YouTube Tarik Video: Indonesia Bangkit Ahmad Dhani,http://showbiz.metrotvnews.com/read/2014/06/28/2583 54/youtube-tarik-video-indonesia-bangkit-ahmad-dhani Accessed at October 1st, 2014).

[3] Baxter, Leslie and Babbie. (2004). the Basics of Communication Research. Canada: THOMSON WADSWORTH.

[4] Castells, Manuel. (2009). Communication Power. Oxford: Oxford University Press.

[5] Charon, Joel M. (2007). Symbolic Interactionism, an Introduction, an Interpretation, Integration: Ninth Edition. New Jersey: Pearson.

[6] Dian, Mas. (2002). Pengaruh Warna dalam Feng Shui (The Impact of Colors in Feng Shui). Jakarta: PT. Elex Media Komputindo.
[7] Fadli Zon "Indonesia Bangkit" Ahmad Dhani Video Klip Terbaik di Pemilu Kali ini. http://www.jpnn.com/read/2014/06/27/242786/Fadli-Zon:Indonesia-Bangkit-Ahmad-DhaniVideoklip-Terbaik-diPemilu-Kali-Ini- . Accessed at October 1st, 2014

[8] Gibraltar, Muhamad. (2014). Viewers Interpretation of Myth: A Semiotic Analysis of Natural Extract Fiber Brand $X$ Commercials Aired on Televisions from 2009-2011. Inside Science PG Journal of Humanities and Social Sciences, 96-107.

[9] Gibraltar, Muhamad (Theses). (2012). Interpretasi Pemirsa Terhadap Penanda dan Petanda (Analisis Semiotika Iklan Sari Serat Alami Merek X di Televisi antara Tahun 2009-2011). Jakarta: Magister Ilmu Komunikasi UI.

[10] Gibraltar, Muhamad. (2014) Comparison Between Interpretation of Viewers in Cultural and in Industrial Cities on The Myth: A Semiotic Analysis of the Indonesian Action Film The Raid 2 Berandal. Inside Science PG Journal of Humanities and Social Sciences, 121-131.

[11] Langer, Susanne K. (1967). An Introduction To Symbolic Logic: Third Revised Edition. New York: Dover Publications, INC.

[12] Lindlof, Thomas R dan Taylor. (2002). Qualitative Communication Research Methods (Fourth Edition). London and New Delhi: Sage Publications.

[13] Littlejohn, Stephen and Foss. (2007). Theories of Human Communication: Seventh Edition. New Mexico: THOMSON

[14] Miller, Katherine. (2005). Communication Theories: Perspectives, Processes, and Contexts (Second Edition). Singapore: McGraw Hill.

[15] Minichiello, Victor et al. (1995). In-Depth Interviewing: Second Edition. Malaysia: Longman Australia Pty Ltd.

[16] Neuman, W. Lawrance. (2006). Social Research Methods: Qualitative and Quantitative Approaches (Sixth Edition). United States of America: Pearson International Edition.

[17] Nurhidayat, Dedy. (2002). Kumpulan Bahan Kuliah Metode Penelitian Komunikasi 1: Program Studi Ilmu Komunikasi (Compilation of Lecture Materials of Communication Research Method 1: Communication Sciences Study Program). Jakarta: University of Indonesia.

[18] Patton, Michael Quinn. (2002). Qualitative Research's Evaluation Methods. London: Sage Publications.

[19] Sobur, Alex. (2009). Semiotika Komunikasi (Semiotics of Communication). Bandung: Rosdakarya.

[20] Soekanto, Soerjono. (1993). Kamus Sosiologi: Edisi Baru (Dictionary of Sociology: New Edition). Jakarta: PT. Raja Grafindo Persada.

[21] Soeprapto M.S, Riyadi. (2002). Interaksionisme Simbolik: Perspektif Sosiologi Modern (Symbolic Interactionism: Perspective of Modern Sociology). Yogyakarta: AVERROES PRESS.

[22] Straw, Will. (2005). Cultural Scenes. Inside Loisir et société/Society and Leisure, vol. 27, no. 2 (autumn, 2004), pp. 411-422.Quebec: Presse de 1'Universite' du Quebec.

[23] Sulasmi, Darmaprawira. (2002). Warna: Teori dan Kreativitas Penggunaannya: Edisi Kedua (Colors: Theory and Creativity in Using Them: Second Edition). Bandung: Bandung Institute of Technology. 
[24] Tim Prabowo Hatta Minta Ahmad Dhani Klarifikasi Video Klip Beratribut Nazi. http://www.voaindonesia.com/content/tim-prabowo-hattaminta-ahmad-dhani-klarifikasi-video-klip-beratribut-nazi/1945267.html. Accessed at October 1st, 2014
[25] Wibowo, Indiwan Seto Wahyu. (2011). Semiotika Komunikasi: Aplikasi Praktis bagi Penelitian dan Skripsi Komunikasi (Semiotics of Communication: Practical Application for Communication Research and Bachelor Level Thesis). Jakarta: Mitra Wacana Media. 